\title{
The Limits of Eclecticism in Consumer Law: National Struggles and the Hope for a coherent European Contract Law. A Comment on the ECJ's and the FCJ's "Heininger"- decisions
}

\author{
By Gralf-Peter Calliess
}

[1] By order of 29 November 1999 the Federal Court of Justice (Bundesgerichtshof) (1) referred to the European Court of Justice (ECJ) for a preliminary ruling under Article $234 \mathrm{EC}$ two questions regarding the interpretation of the "doorstep-selling directive" (2), and the "consumer credit directive" (3), which arose in the course of proceedings involving Mr and Mrs Heininger, who took out from the Bayerische Hypo- und Vereinsbank AG bank a loan to purchase a flat, secured by a charge on the property (Grundschuld). Five years later they sought to cancel the credit agreement, maintaining that an estate agent had called uninvited at their home and induced them to purchase the flat in question and - at the same time acting on a self-employed basis as agent for the bank - to enter into the loan agreement, without informing them of their right of cancellation.

[2] Article 1 para. 1 of the doorstep-selling directive provides that it applies to contracts under which a trader supplies goods or services to a consumer and which are concluded during a visit by a trader to the consumer's home where the visit does not take place at the express request of the consumer'. Article 3 para. 2 a) of that directive provides that the directive shall not apply to contracts for the construction, sale and rental of immovable property or contracts concerning other rights relating to immovable property. Article 4 of the directive provides that traders shall be required to give consumers written notice of their right of cancellation. Article 5 provides that the consumer shall have the right to cancel the contract within seven days from receipt by the consumer of the notice.

[3] Article 2 of the consumer credit directive provides that it shall not apply to credit agreements intended primarily for the purpose of acquiring or retaining property rights in land or in an existing or projected building, and that Article 1 a) and Articles 4 to 12 of the directive shall not apply to credit agreements, secured by mortgage on immovable property.

[4] The German legislation transposing the doorstep-selling directive (the "HWiG") (4) provides for a right of cancellation by the consumer within a period of one week, if a transaction is entered into away from the trader's business premises. The cooling-off period does not start to run until the customer receives a notice in writing containing information on this right and if that notice is not given, the right of cancellation will not lapse until one month after both parties have performed their obligations under the agreement in full. Section 5 para. 2 of the HwiG (5) provides that where the transaction also falls within the scope of the legislation transposing the consumer credit directive (the "VerbrKrG") (6), only the provisions of the latter are to apply.

[5] Section 3 para. 2 of the VerbrKrG (7), in setting out the exceptions to the scope of that law, provides that inter alia Section 7 (right of cancellation) (8) shall not apply to credit agreements in which credit is subject to the giving of security by way of a charge on immovable property, and is granted on usual terms for credits secured by a charge on immovable property and the intermediate financing of the same.

[6] Given this legal framework it is obvious that the Heiningers could not cancel the credit agreement according to the VerbrKrG. Although the agreement constitutes a consumer credit under section 1 VerbrKrG, the right of revocation is excluded by section 3 para. 2 VerbrKrG, the exclusion of which is backed by the consumer credit directive. Although the credit agreement was entered into away from the banks business premises, they as well could not cancel it under the HWiG since this law is not applicable to consumer credit agreements. Thus, the claim of the Heiningers was denied by German courts (9) until the Federal Court of Justice raised the question, if the subsidiarity clause in section 5 para. 2 of the HWiG constitutes a contradiction to the provisions of the door step selling directive. 


\section{Justice's Decision of 9 April 2002}

[7] On 13 December 2001, the ECJ ruled that the doorstep-selling directive applies to a secured-credit agreement and that the directive precludes the national legislature from imposing a time-limit of one year from the conclusion of the contract within which the right of cancellation may be exercised, where the consumer has not received the information specified in Article 4. (10)

[8] In his decision of 9 April 2002 the Federal Court of Justice, hence, ruled that the subsidiarity clause in section 5 para. 2 of the HWiG has to be interpreted restrictively in conformity with the door step selling directive in a way, that the right of revocation under the HWiG shall not be excluded, if the VerbrKrG is not providing the same level of protection to the consumer, which is the case with credit agreements, secured by mortgage on immovable property. (11)

[9] So far so good, one might think. The ECJ, in treating consumer rights as if they were fundamental freedoms ("singularia non sunt extenda" etc.), has once again given an example of its "hard-core" consumer protection approach, implemented by a from the German point of view quite strange and somewhat outdated very formalistic approach to the interpretation of the wording of directives, thereby denying any attempt to establish some coherent principles of European consumer law across the multitude of inconsistent directives. And the Federal Court of Justice, used to a much more policy-oriented approach to adjudication which intends to establish an objective rationale of laws by keeping in mind the factual outcomes of norm interpretation with regard to the involved social interests (the so-called "objektiv-teleologische" and the "folgenorientierte Auslegung"), finally gave in and tried to make the best of the given inconsistencies of European consumer directives. (12)

\section{Consumer Protection Law: For Better or For Worse?}

[10] This is, however, not the end of the story. The decisions of the ECJ and the Federal Court of Justice were already criticised for "giving stones instead of bread" to the consumers since the legal result of the revocation of the credit agreement under the HWiG is, that the Heiningers are obliged to pay back the credit valuta to the bank, while the bank has to return all received payments on interest etc. This will amount to an advantage to the Heiningers only, if the interest rate laid down in the credit agreement was above the market rate available at the time of the conclusion of the contract. The real problem of the many investors like the Heiningers is, however, not the interest rate, but the mere fact the flat was sold to them at a price which often doubles the market value. At the end of the day, the investors even after ten years are not able to pay back the credit by selling the flat, and the income of the investors by renting out the flat is not sufficient to cover the monthly credit rates. (13)

[11] The investments like that of the Heiningers can be understood only on the background of the excessive income tax deductions, which the German government provided within the framework of its "recovery east" (Aufbau Ost) programmes after the German reunification. Banks than allied with building enterprises in order to market renovated flats in the former GDR to tax-payers in West-Germany, which shortly before Christmas were invaded at their homes or offices by an armada of so called "independent advisors" claiming, that their offer is more or less the last chance to participate in the tax-deductions and usually never left the investors living-rooms before the contracts including the credit agreements - were signed. In this very complex marketing system there were, however, so many persons and firms involved, that the marketing and service fees, which had to be hidden somewhere in the price of the flat, equalled or even overrode the tax deductions of the investors. The point is, that the involved banks knowingly financed up to 100 per cent of the sales price of the flats, thereby giving the investors the impression that the price is somehow market-oriented. Since the sellers and marketers of the flats usually are insolvent or go bankrupt after a while, the only chance for recovery of loss of the investor is with the banks. (14)

[12] Such recovery is provided for in section 9 of the $\operatorname{VerbrKrG~(15),~if~the~credit~agreement~and~a~sales~}$ contract are interconnected agreements. Then the investor could transfer the property to the bank and in turn would not be obliged to pay back the credit sum. However, as already said, the VerbrKrG is not applicable to credit agreements secured by mortgage on immovable property. And the HWiG does not provide a comparable clause on interconnected agreements. The Federal Court of Justice in his decision already indicated, that in the Heininger case both contracts are not interconnected. And this is in fact a big relief for the banks, especially for 
the Hypo- und Vereinsbank AG, which is said to have financed a substantial amount of the "recovery east" transactions and which otherwise would have to fear to receive thousands of non-marketable flats in turn for its credits. (16) However, this question remains to be decided by the Court of Appeal, to which the Heininger case was referred by the Federal Court of Justice for final decision.

\section{The Context of Reforming the German Law of Obligations (Schuldrecht)}

[13] Now this still is not the end of the story. For in the German legislation on the modernisation of the law of obligations all the different consumer protection laws, which are based on European directives (17), were reintegrated into the German civil code (BGB). And in an attempt to systematise the different consumer rights in order to make them more coherent and consistent, the different rights of revocation with the differing cooling-off periods, information obligations, exclusion periods in the case of non performance of the information obligation, the rules for the return of received products and services in case of a revocation, etc. were harmonised in single and general rules. (18) The legislator was warned early enough by academics, which claimed that such an attempt of a re-codification of private law is not possible in a situation, where the German legislator with a view to the European consumer directives does not have the necessary competencies, which are necessary to harmonise consumer protection laws. (19) In other words, where there is no coherence and consistency on the European level, there can be none on the national level. (20) The German Ministry of Justice, however, wanted to re-shape the BGB towards a kind of model-law for a European Civil Code to come. (21)

[14] The bill for this unlucky attempt was now presented, when the renewed "model-codification" had to be substantially changed only five months after it had entered into force. In an Act adopted by Parliament on 7 June 2002 (22) and coming into force 1 July 2002, the whole concept of the uniform right of revocation was changed as a response to the ECJ's Heininger decision. The subsidiarity clause in section $312 \mathrm{a}$ BGB is amended in order to secure, that it is applicable only if the consumer actually has another right of revocation. The concept of section 355 para. $3 \mathrm{BGB}$, which provides that the exercise of all rights of revocation is limited to a period of 6 months after the contract was concluded (23), is completely altered. The amended version now provides that all rights of revocation (not only in the door step selling case) are unlimited, if the consumer was not correctly informed on this right. However, the Ministry of Justice will provide a "model information clause" which constitutes a safe harbour: businesses which use this clause are deemed to have informed the consumer correctly. The right of revocation for consumer credits secured by mortgage on immovable property is no longer excluded (sections 491 para. 3 and 495 BGB), but in turn the definition of "interconnected contracts" in section $358 \mathrm{BGB}$ is amended, in order to secure that credit agreements and sales contracts on immovable property are not taken as interconnected in unjustified cases. A lot of smaller amendments follow from others. (24) It takes no clairvoyant to foresee that this was not the last amendment of the BGB to come. The once called "classical" codification of German private law in the BGB now is turned into a continuous work in progress, where one turbo-legislative amendment follows the other, each producing substantial transaction costs to be borne by German businesses.

\section{E. National Private Law and the Emergence of European Private Law Principles}

[10] The solution of this problem cannot simply be a German one. It is for the EU to develop systematic and coherent principles of a European (consumer) contract law. (25) While until lately one could have had the impression that neither the ECJ nor the Commission saw any problem with the non-systematic consumerdirective eclecticism, the Commission in its "Communication on European Contract Law" of July 2001, and then in its "Green Paper on EU Consumer Protection" of October 2001 suddenly took a critical view on the inconsistencies produced by the uncoordinated approach of EC Consumer legislation (26), which up to now left it to political opportunism and pure chance, which specific sectors would be regulated, and which legal principles (if any) would guide such regulation. If a single economic market has to be complemented by the notion of a "European judicial area", the traditional European consumer legislation in no way promoted this aim, but to the contrary resulted in an even deeper fragmentation of the member states private laws.

[15] This is not only because the different directives do not follow a coherent strategy as it is highlighted in the Heininger case, where one might expect that both the door step selling directive and the consumer credit directive would constitute a common principle of non applicability to contracts involving immovable property, 
but in fact $>$ at least in the formalistic interpretation of the ECJ $>$ did not. One might as well expect the directives to follow a coherent definition of the consumer, to provide for a uniform cooling-off period and an absolute limitation period for the exercise of such rights of revocation, but as the ECJ told us there is no such common principles. Moreover, should not be there a common rationale for the provision of rights of revocation?

[16] However, this absence of any coherent principle in the substance is not even the worst thing with the current regulation. The very basic problem with all European private law directives is, that they do follow the "minimum harmonisation approach" established in the Commissions White Paper on the single market back in 1986, but do not provide for the "mutual recognition" of private laws in the non-harmonised fields ("home-state principle" or "country of origin approach"), which is inherent to the so-called "Cassis-Philosophy". (27) The 1980 Rome Convention (28) on the Law applicable to Contractual Obligations abolished the traditional homestate principle of Private International Law in the case of cross-border consumer contracts. The newly established consumer-state principle in connection with the fact, that the minimum harmonisation directives are ? without any objective rationale - transposed into national private laws in very different ways, here and there providing a so-called "higher level of protection" (is a cooling-off period of ten working days really a substantially higher level of protection than a period of two weeks?), led to a situation of complex fragmentation of private laws, which would not have existed without such directives. As is highlighted by the Lando-Principles (29), the traditional national private law systems outside of the new consumerism are still guided by common European principles. With a deepening Common Market in Europe and growing globalisation catalysed by E-Commerce the consumer-state principle may turn out detrimental to consumers especially in smaller member-states. For who would invest in the adaptation of standardised contract clauses and marketing practices for a couple of consumers in lets say Luxembourg or Lithuania? (30)

[17] Although the solution of this problem by an European Civil Code still seems to be a dream, the realisation of which is left to generations to come, there finally is some insight at the Commissions level. In the new Consumer Policy Strategy 2002-2006 which was published on 2 June 2002, the Commission states:

"It is also important that consumers have comparable opportunities to benefit fully from the potential of the internal market in terms of greater choice, lower prices, and the affordability and availability of essential services. Barriers to cross-border trade should therefore be overcome in order that the consumer dimension of the internal market can develop in parallel with its business dimension. EU consumer policy therefore aims at setting a coherent and common environment ensuring that consumers are confident in shopping across borders throughout the EU. ... Likewise businesses are frequently unclear about what practices they should follow if they sell to consumers in other Member States. It is therefore essential for the European Union to ensure that internal market rules and practices promote consumer confidence in cross-border transactions. This implies simpler and more common rules, a similar level of enforcement across the EU, more accessible consumer information and education and effective redress mechanisms. ... There is also a need to review and reform existing EU consumer protection directives, to bring them up to date and progressively adapt them from minimum harmonisation to full harmonisation' measures. The Green Paper [on Consumer Protection of October 2001, GPC] and the Commission's Strategy on Services make it clear that the simple application of mutual recognition, without harmonisation, is not likely to be appropriate for such consumer protection issues. However, provided a sufficient degree of harmonisation is achieved, the country of origin approach could be applied to remaining questions. ... [As a follow up to the Communication on European Contract Law of July 2001 the Commission intends to] propose co-ordination of research activities. These activities could lead to the elaboration of a general frame of reference, establishing common principles and terminology. Furthermore it could explain which measures would be taken to ensure coherence of the existing and future acquis, taking into account the general frame of reference. In this context, a review of existing consumer contract law in order to remove existing inconsistencies, to fill gaps and to simplify could be envisaged. Harmonisation of the coolingoff periods of several Directives would also be part of this review." (31)

[18] The quoted passages of the new consumer strategy of the Commission are highly promising in that for the first time the real problems of European consumer contract law are openly addressed. These problems are now on the agenda of politicians as well as amongst academics, which do not only work together in cross-border research projects like the "Commission on European Contract Law" (32) or the follow-up project of the "Study Group on a European Civil Code" (33), but recently have united in the "Society of European Contract Law" (34) in order to discuss these issues and to establish a common European legal culture amongst private law 
scholars. That is to say, there are interesting times to come for private lawyers in Europe and it is to be hoped, that as well the ECJ will leave its formalistic hard-core consumerism approach in order to contribute for his part in the creation of a common rationale and of general principles of European private law.

(1) Federal Court of Justice (Bundesgerichtshof), the decision is published in: (2000) Wertpapiermitteilungen [WM] p. 26.

(2) Directive 85/577/EEC (OJ 1985 L 372, p. 31): available at http://europa.eu.int/comm/consumers/policy/developments/door sale/index en.html

(3) Directive 87/102/EEC (OJ 1987 L 42, p. 48) as amended by Directive 90/88/EEC (OJ 1990 L 61, p. 14) and in the meantime as well amended by Directive $98 / 7 / \mathrm{EC}$, which was not relevant in the ECJ-Case: all available at http://europa.eu.int/comm/consumers/policy/developments/cons_cred/index en.html

(4) Gesetz $>$ ber den Widerruf von Haust ryesch ften und $\$$ hnlichen Gesch ften, of 16 January 1986 (BGBl. [official Bulletin] I p. 122), which has been integrated into the the German Civil Code (the "BGB") as of 1 January 2002, [i.e. now section 312 BGB] by means of the Legislation on the Modernisation of the Law of Obligations (Gesetz zur Modernisierung des Schuldrechts, of 26 November 2001, BGBl. I p. 3138). For extensive information and references, see http://www.lrz-muenchen.de/ Lorenz/schumod/

(5) Now section 312 a BGB.

(6) Verbraucherkreditgesetz vom 17.12.1990 (BGB1. I 2840), today incorporated into sections $491 \mathrm{ff}$. BGB, see Markus Artz, Neues Verbraucherkreditrecht im BGB, in: Tobias Helms et al. (ed.), Das neue Schuldrecht, Jahrbuch Junger Zivilrechtswissenschaftler 2001, Stuttgart 2001: available at http://www.jura.unifreiburg.de/Junge.Zivilrechtswissenschaftler/Freiburg2001/Tagungsband/Artz.pdf

(7) Now section 491 para. 3 No. 1 BGB.

(8) Now section 495 BGB.

(9) The lower Court decisions being published in: WM 1998, 1723 and WM 1999, 728.

(10) EUGH Decision of 13 December 2001 (C-481/99) "Heininger v Bayerische Hypo- und Vereinsbank AG", (2002) Zeitschrift $>$ r Bank- und B rsenrecht [ZBB], p. 29; also available at http://curia.eu.int/jurisp/cgi-bin/form.pl?lang $=$ en $\&$ Submit $=$ Submit\&docrequire $=$ alldocs\&numaff $=\mathrm{C}$ 481\%2F99\&datefs=\&datefe=\&nomusuel $=\&$ domaine=\&mots=\&resmax=100; see also the "Opinion of the General Advocate of 12 July 2001", available at http://curia.eu.int/jurisp/cgi-bin/form.pl? lang $=$ en $\&$ Submit $=$ Submit $\&$ docrequire $=$ alldocs $\&$ numaff $=\mathrm{C}-$ $\underline{481 \% 2 \mathrm{~F} 99 \& \text { datefs }=\& \text { datefe }=\& \text { nomusuel }=\& \text { domaine }=\& \text { mots }=\& \text { resmax }=100}$

(11) BGH Decision of 9 April 2002 (XI ZR 91/99) ZBB 2002, p. 194: available at http://www.rws-verlag.de/

(12) For a discussion see Peter Derleder, Der Widerruf des Haust rrgrundpfandkredits, ZBB 2002, p. 202. See also the references in the BGH decision of 9 April 2002.

(13) See the information given and the various links at http://www.immogeschaedigt.de/Aktuelles.htm

(14) See for the background J rrg St sser, Bankenhaftung bei gescheiterten Immobilien-Treuhandmodellen, in: Neue Juristische Wochenschrift [NJW] 1999, 1586.

(15) Now section 358 BGB.

(16) Vgl. DIE ZEIT http://www.zeit.de/2002/14/Wirtschaft/200214 schrottgrundstue.html and http://www.zeit.de/2002/24/Wirtschaft/200224_zwischenruf.html

(17) In addition to "doorstep-selling" and "consumer credits" as well "distant selling", "package travel", and 
"unfair contract terms": see http://europa.eu.int/comm/consumers/index_en.html

(18) Schmidt-R ntsch, Reintegration der Verbraucherschutzgesetze durch den Entwurf eines

Schuldrechtsmodernisierungsgesetzes, in: Schulze/Schulte-N>lke (eds.), DIE SCHULDRECHTSREFORM

VOR DEM HINTERGRUND DES GEMEINSCHAFTSRECHTS 169 ff. (2001).

(19) See Christoph Safferling, Re-Kodifizierung des BGB im Zeitalter der Europ isierung des Zivilrechts ein Anachronismus?, in: Tobias Helms et al. (eds.), DAS NEUE SCHULDRECHT, Jahrbuch Junger

Zivilrechtswissenschaftler 2001, Stuttgart 2001: available at http://www.jura.uni-

freiburg.de/Junge.Zivilrechtswissenschaftler/Freiburg2001/Tagungsband/Safferling.pdf

(20) For the related problems see Wulf-Henning Roth, Transposing pointillistic EC guidelines into sys-tematic national Codes - problems and consequences, contribution to the Rome Conference of Secola, June 2001; see also the contributions to Grundmann/Medicus/Rolland (eds.), EUROP $>$ ISCHES

KAUFGEW $>$ HRLEISTUNGSRECHT (2000).

(21) Peter Schlechtriem, Entwicklung des deutschen Schuldrechts und europ ische

Rechtsangleichung, in: Tobias Helms et al. (eds.), DAS NEUE SCHULDRECHT, Jahrbuch Junger

Zivilrechtswissenschaftler 2001, Stuttgart 2001: available at http://www.jura.uni-

freiburg.de/Junge.Zivilrechtswissenschaftler/Freiburg2001/Tagungsband/Schlechtriem.pdf

(22) Bundestag Drucksache 14/9266, available at http://dip.bundestag.de/ (= Dokumentation in ZBB 2002, 233 available at http://www.rws-verlag.de/), and Bundesrat Drucksache 503/02, available at

http://www.parlamentsspiegel.de/cgi-bin/hyperdoc/show dok.pl?k=BBD503/02

(23) Peter Mankowski, Zur Neuregelung der Widerrufsfrist bei Fehlen einer Belehrung im

Verbraucherschutzrecht, in: (2001) Juristenzeitung [JZ] pp. 745 ff.

(24) See the overview in Derleder, supra note 12, pp. $209 \mathrm{ff}$.

(25) And not only for consumer contracts: see Stefan Grundmann, Consumer Law, Commercial Law, Private Law - how can the Sales Directive and the Sales Convention be so similar?, presentation at: Rome conference of Secola, June 2001.

(26) Communication on European Contract Law, COM 398 (2001) final, including the responses to the communication and follow-up documents available at

http://europa.eu.int/comm/consumers/policy/developments/contract_law/index en.html ; Green Paper on EU

Consumer Protection, COM(2001) 531 final, available at http://europa.eu.int/comm/consumers/, which was

discussed on the London Secola Conference in May 2002 (www.secola.org); hereto, see also ..., (2002)

European Review of Private Law p. .

(27) See ECJ of 20 February 1979 (C 120/78) "Cassis de Dijon"; and the Commission White Paper on the Single Market COM (1985) 310; see also Astrid Epiney in: Calliess/Ruffert (eds.), KOMMENTAR ZUM EUV UND EGV, 2nd Ed. July 2002, Art. 28 EGV (EC-Treaty) No. 20 et seq.

(28) See http://www.rome-convention.org/

(29) Available at http://www.cbs.dk/departments/law/staff/ol/commission_on_ecl/pecl full text.htm

(30) For the concept of transaction costs in international trade see Matthias Busse, Transaktionskosten und Wettbewerbspolitik, Wirtschaft und Wettbewerb (WuW) 2002, 112; for the relevance of legal transaction costs see Gralf-Peter Calliess, Rechtssicherheit und Marktbeherrschung im elektronischen Welthandel, in: Juergen Donges/Stefan Mai (eds.), E-COMMERCE UND WIRTSCHAFTSPOLITIK 189 (2001), available as pdf-file at www.uni-frankfurt.de/fb01/teubner

(31) Consumer Policy Strategy 2002-2006, COM(2002) 208 final, available at http://europa.eu.int/comm/consumers/ 
(32) See http://www.cbs.dk/departments/law/staff/ol/commission_on_ecl/

(33) See http://www.sgecc.net/

(34) See http://www.secola.org; see also the contributions to the Leuven Conference of Secola in November 2001, to be published in Grundmann/Stuyck (eds.), AN ACADEMIC GREEN PAPER ON EUROPEAN CONTRACT LAW, forthcoming July 2002, with Kluwer. 